\title{
PENGEMBANGAN ATRIBUT PRODUK KERIPIK SINGKONG MENGGUNAKAN METODE VALUE ENGINEERING BERBASIS CUSTOMER ORIENTED
}

\section{DEVELOPMENT OF CASSAVA CHIPS ATTRIBUTES USING CUSTOMER-ORIENTED VALUE ENGINEERING}

\author{
Muhammad Indra Darmawan*), Mariatul Kiptiah, Adzani Ghani Ilmannafian, Maulida Safitri \\ Program Studi Agroindustri, Polteknik Negeri Tanah Laut, Pelaihari \\ Jl. A.Yani Km 06, Panggung, Kec. Pelaiharu, Kab. Tanah Laut, Kalimantan Selatan, Indonesia \\ Email: mindradarmawan@ politala.ac.id
}

Makalah: Diterima 16 November 2020; Diperbaiki 31 Maret 2021; Disetujui 10 April 2021

\begin{abstract}
The development of the home industry and the challenges during the pandemic have prompted the need for innovation, especially in the marketing mix aspect of MSME products. The development of this aspect will propel MSME products to compete in the modern retail industry. This effort was implemented in Mr Baihaqi's cassava chips business, which according to preliminary research, needs to develop its product aspects, especially on the packaging and labeling. This study aimed to determine recommendations for cassava chips' development using the value engineering method based on customer-oriented. The research stage consisted of eight stages, i.e. preparation, information, function analysis, creative, evaluation, development, presentation, and implementation. The preparatory stage involved identifying the problem; the information stage consisted of collecting information from consumers through online questionnaires. The function analysis stage was carried out by analysing online questionnaires, and the creative stage was carried out by making alternative combinations of packaging and labels. Furthermore, the evaluation stage was carried out by testing the acceptance of panellists through filling out a pairwise comparison questionnaire, the development stage through a business feasibility analysis based on Cost of Goods Sold (COGS), Break-Even Point (BEP), Net Present Value (NPV), and Internal Rate of Return (IRR). The final stage was the presentation of the recommendations to the business owner and the implementation stage. The results showed that product development's priority was standing plastic pouch packaging using topdown labels with a value of 0.160. The COGS obtained was Rp 4,063.97, BEP production of Rp 404,232.80, BEP units of 57.75 packs, NPV of Rp 8,533,018.84, and IRR of $41.91 \%$.
\end{abstract}

Keywords: cassava chips, marketing mix, value engineering

\begin{abstract}
ABSTRAK
Perkembangan industri rumah tangga dan tantangan dalam masa pandemi mendorong perlunya inovasi terutama dalam aspek bauran pemasaran. Pengembangan aspek ini akan membuat produk UMKM dapat bersaing di industri retail modern. Upaya ini diimplementasikan pada usaha keripik singkong Bapak Baihaqi yang menurut penelitian pendahuluan perlu mengembangkan aspek produk, terutama pada kemasan dan label. Tujuan penelitian ini adalah menentukan rekomendasi pengembangan produk keripik singkong menggunakan metode value engineering berdasarkan pada customer oriented. Penelitian terdiri atas delapan tahapan, yaitu persiapan, informasi, analisis fungsi, kreatif, evaluasi, pengembangan, presentasi, dan implementasi. Tahapan persiapan melibatkan identifikasi masalah, tahapan informasi berisi pengumpulan informasi dari konsumen melalui kuesioner daring, tahapan analisis fungsi dilakukan analisis dari kuesioner daring, dan tahapan kreatif dilakukan dengan membuat alternatif kombinasi kemasan dan label. Selanjutnya, pada tahapan evaluasi dilakukan uji penerimaan panelis melalui pengisian kuesioner perbandingan berpasangan, tahapan pengembangan melalui analisis kelayakan usaha berdasarkan Harga Pokok Produksi (HPP), Break Even Point (BEP), Net Present Value (NPV), dan Internal Rate of Return (IRR). Tahapan akhir adalah presentasi hasil rekomendasi kepada pemilik usaha dan tahapan implementasi. Hasil penelitian menunjukkan bahwa prioritas pengembangan atribut produk adalah dengan kemasan plastik standing pouch menggunakan label atas bawah dengan nilai 0,160 . HPP yang diperoleh sebesar Rp 4.063,97, BEP produksi sebesar Rp 404.232,80, BEP unit sebanyak 57,75 bungkus, NPV sebesar Rp 8.533.018,84, dan IRR 41,91\%.
\end{abstract}

Kata kunci: bauran pemasaran, keripik singkong, rekayasa nilai

\section{PENDAHULUAN}

Perkembangan usaha industri rumah tangga yang memiliki usaha yang menjanjikan, dalam pengolahan keripik singkong dilakukan oleh salah satu industri rumah tangga milik Bapak Baihaqi yang berada di Jl. Swadaya RT 02 RW 01 No. 52 Desa Bumi Harapan, Kecamatan Bumi Makmur, Kabupaten Tanah Laut. Produk yang dihasilkan dipasarkan langsung baik di jual di rumah maupun di

*Penulis Korespondensi 
pasar tradisional. Produk keripik singkong ini sebenarnya terbuka untuk dipasarkan di retail modern dan mendapat fasilitasi serta dorongan dari pemerintah daerah. Usaha keripik singkong ini sudah berjalan selama \pm 8 tahun dan masih belum banyak melakukan pengembangan dalam hal bauran pemasaran (marketing mix). Bauran pemasaran merupakan seperangkat alat pemasaran yang digunakan perusahaan untuk mencapai tujuan pemasaran dalam memenuhi target pasarnya. Bauran pemasaran terdiri atas product (produk), price (harga), promotion (promosi), dan place (tempat dan distribusi).

Pengembangan atribut produk dapat meliputi pengembangan rasa, ukuran, kemasan, dan berat bersih (Rosita et al., 2018), pengembangan warna, aroma, rasa, dan kerenyahan (Sadikin et al., 2015), pengembangan rasa, kemasan, dan berat bersih (Pujianto et al. (2016), serta rasa dan harga (Darmawan et al., 2020). Pengembangan atribut produk pada suatu produk memerlukan peran serta konsumen. Konsumen memiliki preferensi tertentu dan akan mempengaruhi keputusan pembelian dan loyalitas terhadap produk tertentu. Penelitian Piligrimiene et al. (2015) menunjukkan bahwa pelibatan konsumen dalam menambah kreasi nilai pada suatu produk merupakan hal penting dan berdampak positif. Pelibatan konsumen ini membuat pengembangan atribut produk berorientasi pada konsumen (customer oriented). Metode yang dapat digunakan dalam mengembangkan produk berbasis customer oriented adalah menggunakan value engineering (VE).

VE menurut Society of American Value Engineering (SAVE) terdiri atas beberapa tahapan yaitu tahapan persiapan, tahapan informasi, tahapan analisis fungsi, tahapan kreatif, tahapan pengembangan, tahapan presentasi dan tahapan implementasi. Pendekatan VE dalam pengembangan produk skala UMKM terbukti efektif pada pengembangan mutu produk dan kemasan lempuk durian (Wahyudi et al., 2013), produk olahan ikan peperek (Rosita et al., 2018), produk dodol (Pujianto, et al. (2016), serta produk amplang (Darmawan et al., 2020).

Studi awal pada penelitian ini sekaligus tahapan persiapan VE dilakukan dengan mewawancara beberapa konsumen loyal dan pemilik usaha. Hasil studi awal berupa wawancara dengan pemilik usaha mendapatkan informasi bahwa segmen pasar yang dijadikan target adalah usia 20-40 tahun. Usia inilah yang akan dijadikan target responden pada tahapan informasi pada VE. Konsumen loyal memberikan penilaian bahwa aspek yang harus dikembangkan pada produk kripik singkong ini adalah kemasan dan label. Hal ini juga didapatkan dari wawancara dengan pemilik, bahwa banyak konsumen yang menyarankan hal tersebut kepada pemilik usaha, tentunya dengan perubahan kemasan, label, dengan harga terjangkau, produk akan mampu bersaing dan memasuki pasar retail moden.

Menurut penelitian Reven dan Ferdinand (2017), desain dan label kemasan berpengaruh terhadap keputusan pembelian produk. Pada penelitian lain Ishafila et al. (2018), desain dan label kemasan berpengaruh terhadap kepuasan konsumen, sehingga kemasan dan desain label yang akan dibuat harus memperhatikan konsumen sebagai target pasar. Melalui metode VE akan didapatkan profil rancangan label dan kemasan yang sesuai dengan ekspektasi konsumen. Produk keripik singkong perlu dilakukan pengembangan untuk dapat bersaing di pasar retail modern. Upaya ini akan difasilitasi melalui penelitian yang terstruktur berdasarkan tahapan dalam VE. Penelitian ini bertujuan untuk menentukan rekomendasi pengembangan produk keripik singkong menggunakan metode VE berdasarkan pada customer oriented.

\section{METODE PENELITIAN}

Metode penelitian dilakukan dengan metode VE melalui tahapan persiapan, tahapan informasi, tahapan analisis fungsi, tahapan kreatif, tahapan pengembangan, tahapan presentasi dan tahapan implementasi. Pelaksanaan tahapan merujuk pada Society of American Value Engineering (SAVE). Tahapan persiapan, informasi, dan analisis fungsi mengacu pada penelitian Pujianto et al. (2016), sedangkan tahapan evaluasi dan pengembangan mengacu pada penelitian Darmawan et al. (2020).

\section{Tahapan Persiapan}

Tahapan persiapan dilakukan identifikasi masalah dan wawancara dengan pemilik usaha. Pada tahapan ini profil usaha dan upaya pengembangan atribut produk beserta potensinya di diskusikan dengan pemilik usaha. Segmentasi pasar dan rata-rata usia pelanggan produk keripik singkong juga di ambil untuk nanti memudahkan tahapan selanjutnya yaitu tahapan informasi.

\section{Tahapan Informasi}

Pada tahapan ini dilakukan pengumpulan datadata. Tahapan ini adalah tahapan penggalian informasi dan data yang dibutuhkan berdasarkan pertanyaan-pertanyaan pada rencana kerja rekayasa nilai. Responden penelitian pada tahapan informasi berjumlah 60 orang dengan rasio laki-laki dan perempuan dalam jumlah yang sama. Pemilihan responden menggunakan metode purposive sample. Kriteria responden secara khusus adalah laki-laki atau perempuan yang berumur 20-40 tahun sesuai dengan hasil studi pendahuluan dengan pemilik usaha. Atribut produk dalam marketing mix yang di ambil adalah kemasan produk, label, ukuran Kuesioner diisikan secara daring dan mencakup informasi atribut produk berupa jenis kemasan, bahan kemasan, ukuran label, informasi dalam label, harga, prioritas 
pengembangan produk keripik singkong (Reven dan Ferdinand, 2017; Lumanauw dan Karim, 2014). Pada tahapan informasi akan didapatkan perspektif konsumen berkaitan dengan atribut bauran pemasaran yang akan dikembangkan, khususnya berkaitan dengan pilihan kemasan, label, dan harga yang akan ditawarkan.

\section{Tahapan Analisis Fungsi}

Pada tahapan analisis fungsi akan dilakukan analisis hasil kuesioner daring. Pada tahapan ini fokus pada hal yang di prioritaskan untuk memperjelas fungsi yang diperlukan. Label kemasan mulai dirancang dan didiskusikan dengan pemilik UMKM. Hasil dari rancangan ini akan dilanjutkan ke tahapan kreatif.

\section{Tahapan Kreatif}

Pada tahapan ini membuat desain label dan memasukkan produk ke dalam kemasan-kemasan sesuai dengan tahapan informasi yang telah didapat. Pada formulasi yang telah dibuat kemudian ditambahkan dengan rancangan harga. Pada tahapanan kreatif ini akan menggunakan 2 varibel yang masing-masing terdiri dari 3 item pilihan. Berikut adalah rancangan variabel pada tahapan kreatif yang disajikan pada Tabel 1.

\section{Tahapan Evaluasi}

Pada tahapan evaluasi ini alternatif-alternatif yang telah dibuat kemudian dilakukan analisis penerimaan 30 responden dengan umur 20-40 tahun dan jumlah laki-laki dan wanita seimbang. Penentuan 30 responden ini sesuai dengan Standar Nasional Indonesia (SNI) No. 01-2346-2006 tentang Uji Sensori dan Organoleptik (Badan Standardisasi Nasional, 2006). Setiap responden akan diberikan kuesioner perbandingan berpasangan yang selanjutnya akan dianalisis menggunakan expert choice 11. Melalui metode ini akan didapatkan urutan prioritas pengembangan yang dipilih responden sebagai representasi customer oriented. Hasil expert choice 11 dianggap valid jika nilai tingkat konsistensi maksimal 10\% (Rimantho et al., 2016). Penggunaan expert choice untuk jumlah responden jamak didasarkan pada penelitian Akbar (2011) dengan 50 responden dan Santoso et al. (2019) dengan 30 responden.

\section{Tahapan Pengembangan}

Tahapan yang dilakukan untuk mengetahui pengembangan dari analisa produk dilakukan analisis kelayakan berdasarkan harga pokok produksi (HPP) dan break even point (BEP). Perhitungan dilakukan dengan basis 1 bulan produksi dan menggunakan asumsi dalam satu tahun pendapatan dan beban biaya tetap. Perhitungan HPP dan BEP dilakukan sesuai dengan perhitungan yang dilakukan pada penelitian Darmawan et al.(2018), sedangkan perhitungan NPV dan IRR sesuai dengan perhitungan pada penelitian Khotimah dan Sutiono (2014).

$$
\begin{array}{ll}
\mathrm{HPP} & =\frac{\text { Total biaya produksi/bulan }}{\text { Jumlah produksi/bulan }} \\
\mathrm{BEP}(\text { produksi) } & =\frac{\text { Total biaya tetap }}{\text { Harga }-\frac{\mathrm{VC}}{\mathrm{unit}}} \\
\mathrm{BEP}(\mathrm{Rp}) & =\frac{\text { Total biaya tetap }}{\left(\frac{\text { Harga }-\frac{\mathrm{VC}}{\mathrm{unit}}}{\text { Harga }}\right)} \\
\mathrm{NPV} \quad(\mathrm{Rp}) & =\sum_{\mathrm{t}=0}^{\mathrm{n}} \frac{\mathrm{B}_{\mathrm{t}}-\mathrm{C}_{\mathrm{t}}}{(1+\mathrm{i})^{\mathrm{t}}} \\
\mathrm{IRR} & =i_{1}+\frac{N P V_{1}}{N P V_{1}-N P V_{2}} x\left(i_{1}-i_{2}\right)
\end{array}
$$

Keterangan:

$\mathrm{VC}=$ Total Biaya Tidak Tetap

$\mathrm{Bt}=$ Benefit atau manfaat pada tahun ke-t

$\mathrm{Ct}=$ Cost atau biaya pada tahun ke- $\mathrm{t}$

$\mathrm{i}$ = suku bunga yang digunakan

$\mathrm{t}=$ tahun ke- $\mathrm{t}$

$\mathrm{i}_{1}=$ suku bunga yang menghasilkan NPV positif

$\mathrm{i}_{2}=$ suku bunga yang menghasilkan NPV negative

$\mathrm{NPV}_{1}=\mathrm{NPV}$ positif

$\mathrm{NPV}_{2}=\mathrm{NPV}$ negatif

\section{Tahapan Presentasi}

Tahapan presentasi akan dilakukan presentasi rancangan pengembangan terbaik disertai dengan analisis perhitungan secara ekonomi apabila tancangan tersebut di implementasikan.

\section{Tahapan Implementasi}

Tahapan implementasi adalah tahap dimana pemilik usaha melaksanakan rancangan terpilih.

\section{HASIL DAN PEMBAHASAN}

\section{Tahapan Persiapan}

Hasil studi awal berupa wawancara dengan pemilik usaha mendapatkan informasi bahwa segmen pasar yang dijadikan target adalah usia 20-40 tahun. Usia inilah yang akan dijadikan target responden pada tahapan informasi pada VE. Konsumen loyal memberikan penilaian bahwa aspek yang harus dikembangkan pada produk kripik singkong ini adalah kemasan dan label.

Tabel 1. Rancangan variabel tahapan kreatif

\begin{tabular}{ccccc}
\hline \multirow{2}{*}{ Variabel } & \multirow{2}{*}{ Jumlah Item } & \multicolumn{3}{c}{ Item Alternatif Setiap Variabel } \\
\cline { 3 - 5 } & 3 & Label 1 & Label 2 & Label 3 \\
\hline Kemasan 1 & 3 & K1L1 & K1L2 & K1L3 \\
Kemasan 2 & 3 & K2L1 & K2L2 & K2L3 \\
Kemasan 3 & K3L1 & K3L2 & K3L3 \\
\hline
\end{tabular}


Hal ini juga didapatkan dari wawancara dengan pemilik, bahwa banyak konsumen yang menyarankan hal tersebut kepada pemilik usaha, tentunya dengan perubahan kemasan, label, dengan harga terjangkau, produk akan mampu bersaing dan memasuki pasar retail modern.

\section{Tahapan Informasi}

Pada tahapan ini di dapatkan informasi berkaitan bentuk kemasan, bentuk label, dan rentang harga produk yang akan ditawarkan. Pada tahapan ini mengkonfirmasi hasil wawancara awal dengan pemilik usaha dengan konsumen sebagai wujud aspek customer oriented. Konsumen secara umum memprioritasnkan pengembangan atribut produk yaitu kemasan dan label untuk dikembangkan. Pengembangan ini juga menurut responden juga harus mempertimbangkan harga yang akan ditawarkan.

\section{Tahapan Analisis Fungsi}

Pada tahapan analisis fungsi didapatkan bentuk kemasan yang disarankan oleh responden adalah bentuk standing pouch (73\% responden). Pilihan label yang di inginkan konsumen cukup separuh atau sebagian kemasan (50\%), tidak perlu full label dan jangan pula terlalu kecil. Harga produk per 100 gr yang diharapkan konsumen berada pada rentang harga Rp. 5.000 -Rp. 10.000 (86,7\%). Merek dagang yang akan dimasukkan ke dalam desain label adalah "Keripik Singkong ADIFFATIYA". Desain label, pilihan warna, dan kombinasi dengan kemasannya dilanjutkan pada tahapan kreatif.

\section{Tahapan Kreatif}

Hasil dari tahapan analisis fungsi dilanjutkan pada tahapan kreatif. Pilihan konsumen terhadap bentuk kemasan standing pouch akan di tawarkan dengan pilihan bahan plastik, dan semi aluminium foil. Pilihan bahan ini juga disesuaikan dengan harga pilihan konsumen pada rentang harga Rp. 5.000 -Rp. 10.000. Atribut kemasan dapat menjadi prioritas konsumen sekaligus dapat mempengaruhi keputusan pembelian dan persepsi sebuah produk (Sudrajat dan Andriani, 2015; Hanifawati et al., 2017). Pengembangan produk mencakup penetapan manfaat yang akan disampaikan oleh produk melalui kemasan berikut informasi pada labelnya. Manfaat ini dikomunikasikan dan disampaikan oleh atribut produk seperti mutu, sifat, dan rancangan. Menurut Widodo (2010), atribut produk berupa merek, gambar logo, trade mark, maupun label akan mempengaruhi keputusan pembelian konsumen. Produk keripik singkong Bapak Baihaqi sebelumnya tanpa merek dagang tertentu. Kami memberikan saran untuk lebih menguatkan identitas produk pada desain label yang akan dibuat (tahapan analisis fungsi). Desain label berupa informasi, nama merek, dan logo berdasarkan hasil diskusi dengan pemilik usaha. Berikut pada Tabel 2 disajikan alternatif-alternatif pengembangan yang akan ditawarkan pada konsumen.

\section{Tahapan Evaluasi}

Kombinasi nilai bobot dan nilai prioritas alternatif-alternatif pengembangan keripik singkong menurut semua kategori usia yaitu 20-40 tahun dapat dilihat pada Gambar 3 .

Pada penelitian ini nilai konsistensi sebesar 0,03 dan dinyatakan hasilnya valid dan konsisten. Setelah dikombinasikan sebanyak 30 responden maka didapatkan hasil dari kalkulasi nilai bobot menunjukkan bahwa responden memilih alternatif K1L3 sebagai pengembangan produk keripik singkong dengan nilai prioritas sebesar 0,160. Desain produk secara visual akan mampu menarik perhatian konsumen. Desain pilihan konsumen dapat dinilai dari warna, tata letak desain, ilustrasi, pilihan huruf, dan bentuk grafis yang dapat mempengaruhi kepuasan konsumen terhadap suatu produk Amanah (2010). Hal ini berarti kemasan produk memiliki pengaruh terhadap kepuasan pelanggan, sehingga akan lebih baik bila dapat meningkatkan kemasan produk sebagai dasar strategi pemasaran. Menurut penelitian yang dilakukan oleh Lukman (2014), Ishak dan Luthfi (2011), dan Susila et al. (2014) bahwa kepuasan konsumen meliputi citra yang ditimbulkan dari produk tersebut dinilai dapat memenuhi kepuasan konsumen dan menjadikannya berbeda dengan merek para pesaing. Perbedaan yang dapat dilihat dari K1L3 adalah bentuk label berupa label terpisah bagian atas dan bagian bawah, hal ini juga dapat menjadi pembeda dari pesaing sejenis yang kebanyakan menggunakan jenis label L1 dan L2. Kemasan yang masih dipilih adalah K1 yaitu berbahan plastik. Padahal pada penelitian ini konsumen juga diberikan pilihan K3 yaitu kemasan berbahan kertas yang cenderung lebih mudah di daur ulang, namun konsumen cenderung menyukai kemasan yang dapat memperlihatkan isi dalam kemasan (plastik transparan).

\section{Tahapan Pengembangan}

Pada tahapan pengembangan ini dilakukan pengembangan dari segi produk yaitu mengubah kemasan produk yang semula hanya plastik kresek saja menjadi kemasan standing pouch plastik dan menambahkan keterangan label pada produknya. Kemudian dilakukan analisis kelayakan usaha berdasarkan harga pokok produksi (HPP) dan break even point (BEP) dari penggunaan standing pouch plastik beserta label yang dipilih responden. 
Tabel 2. Alternatif Pengembangan Produk

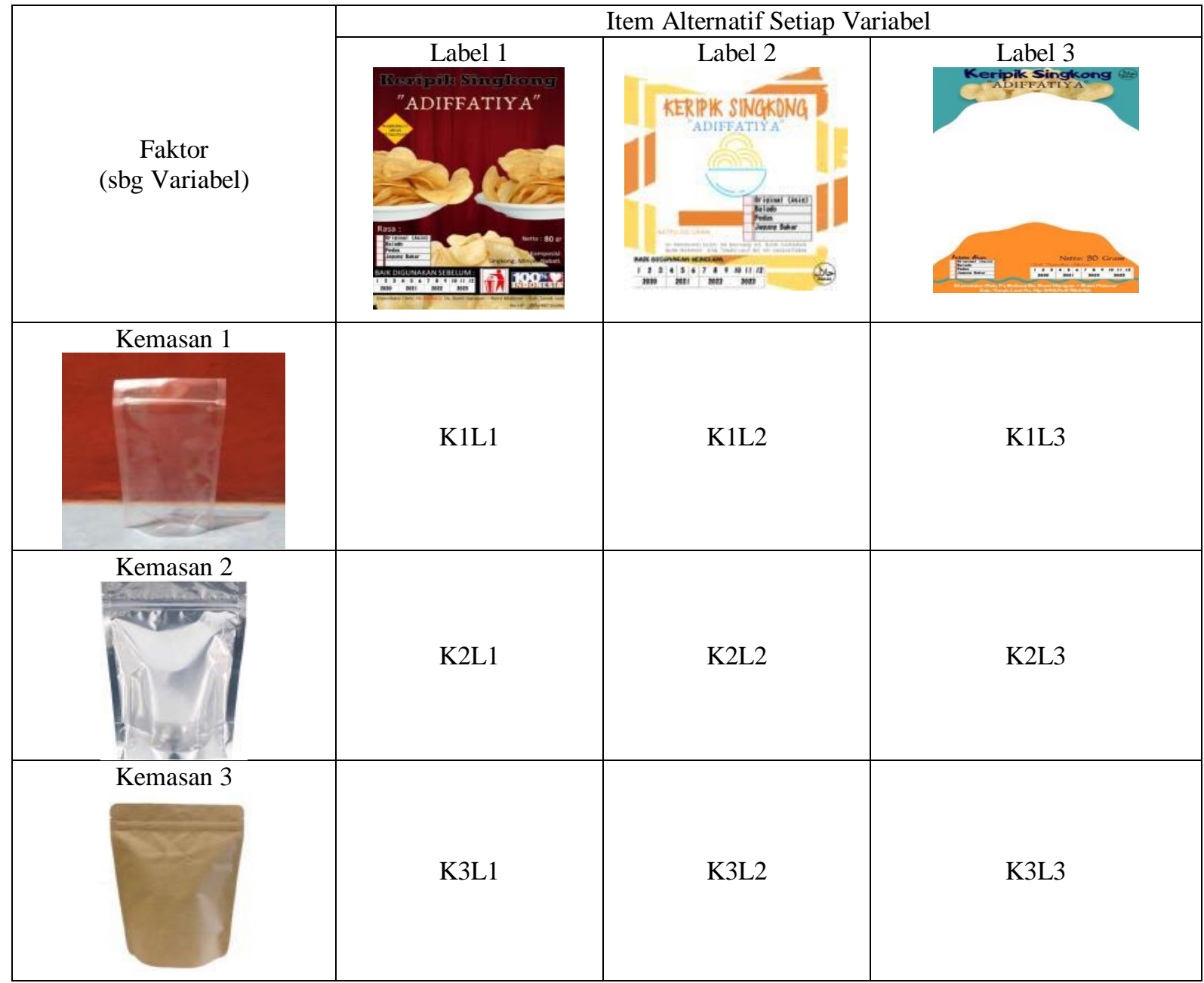

\section{Alternatif \\ Pengem bangan \\ Incon: 0.03}

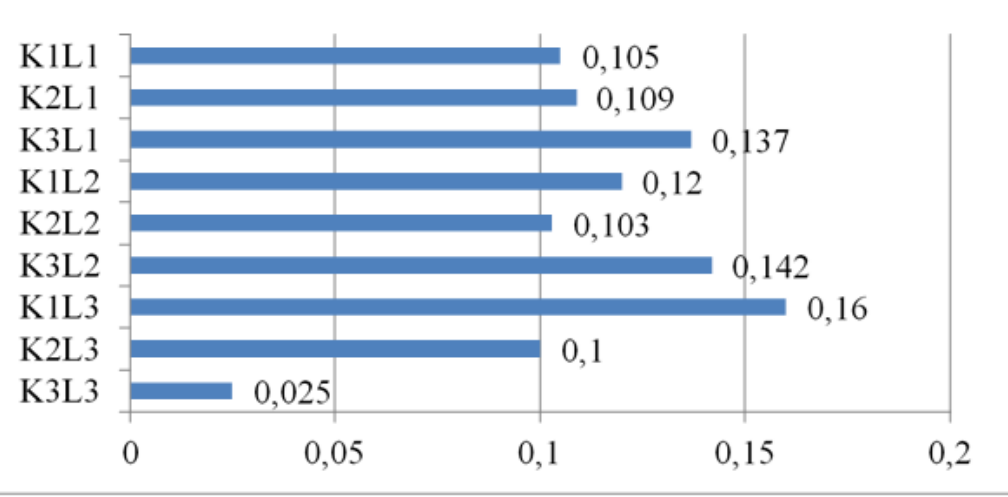

Nilai Prioritas Pengembangan

Gambar 3. Diagram nilai prioritas alternatif-alternatif pengembangan

Berdasarkan hasil biaya produksi, dapat diperoleh hasil pokok produksi (HPP) dengan melakukan perbandingan antara total biaya produksi dengan jumlah produksi selama satu bulan. Berikut merupakan hasil analisis kelayakan usaha keripik singkong dengan waktu produksi yaitu setiap hari dan estimasi harga jual $\mathrm{Rp} \mathrm{7.000/bungkus.} \mathrm{Estimasi}$ didasarkan pada plilihan rentang harga pada tahapan informasi (Rp 5.000 - Rp 10.000). Harga ini juga memperhitungkan proyeksi jika pemilik usaha sepakat untuk menggunakan sistem konsinyasi dan bekerja sama dengan retail modern untuk memasarkan produknya. Berikut pada Tabel 4 disajikan hasil analisis kelayakan usaha pengembangan produk keripik singkong. 
Tabel 4. Analisis kelayakan usaha

\begin{tabular}{|c|c|c|}
\hline No & Jenis Analisa (perbulan) & Hasil \\
\hline 1 & Total biaya tetap & Rp 178.722 \\
\hline 2 & Total biaya tidak tetap & $\operatorname{Rp} 4.393 .250$ \\
\hline 3 & Total biaya produksi & $\operatorname{Rp} 4.571 .972$ \\
\hline 4 & Harga pokok penjualan (HPP) & Rp 4.063,97/bungkus \\
\hline 5 & Perhitungan pokok penjualan & 1.125 bungkus \\
\hline 6 & Perhitungan penjualan & $\operatorname{Rp} 7.875 .000$ \\
\hline \multirow[t]{3}{*}{7} & Laba rugi & \\
\hline & Laba kotor & Rp 3.303.028 \\
\hline & Laba bersih & Rp 3.263.653 \\
\hline \multirow[t]{3}{*}{8} & Break even point (BEP) & \\
\hline & BEP unit & 57,75 bungkus \\
\hline & BEP produksi & $\operatorname{Rp} 404.232,8$ \\
\hline 9 & Net Present Value (NPV) & $\operatorname{Rp} 8.533 .018,84$ \\
\hline 10 & Internal Rate of Return (IRR) & $41,91 \%$ \\
\hline
\end{tabular}

Sensitivitas terhadap perubahan tingkat bunga pasar dilakukan analisis NPV dan IRR. NPV didapatkan sebesar Rp 8.533.018,84 dan IRR $41,91 \%$. NPV bernilai lebih dari 0 menunjukkan bahwa investasi yang dilakukan akan menghasilkan manfaat bagi perusahaan dan proyek layak untuk dijalankan. IRR 41,91\% lebih besar jika dibandingkan dengan nilai suku bunga yang digunakan yaitu $6 \%$, juga menunjukkan rentang yang besar dan dapat disimpulkan bahwa proyek pengembangan kemasan dan label ini layak untuk dijalankan.

\section{Tahapan Presentasi}

Berdasarkan hasil pada tahapan analisis dan pengembangan, dapat diketahui $62 \%$ responden memilih pengembangan pada segi kesaman dan desain label. Menurut hasil analisis menggunakan software expert choice 11 pada alternatif-alternatif yang telah diberikan konsumen lebih memilih menggunakan kemasan standing pouch plastik dengan kode K1L3 dimana label tersebut terletak pada atas dan bawah kemasan yang memudahkan konsumen melihat pada tengah kemasan apa isi produk tersebut. Berdasarkan hal tersebut maka direkomendasikan kepada pemilik usaha bahwa pengembangan keripik singkong tersebut berfokus pada bauran produk dengan alternatif kemasan standing pouch plastk dengan label kombinasi pada bagian atas dan bawah. Berikut disajikan pada Gambar 4 presentasi produk yang direkomendasikan.

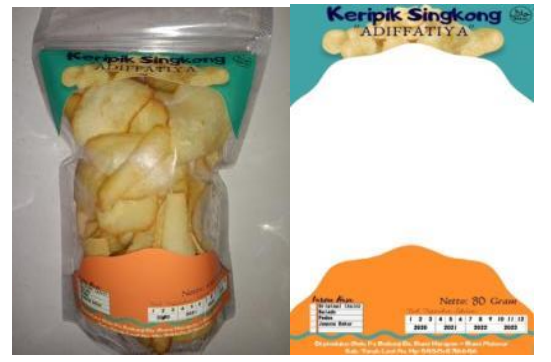

Gambar 4. Rekomedasi kemasan dan desain label
Rancangan pengembangan yang menggunakan kemasan tersebut telah dilakukan perhitungan analisis usaha dengan omset perbulan berkisar Rp 7.875.000 dengan keuntungan sebesar Rp 3.263.653 dan titik impas agar biaya dapat kembali adalah BEP produksi yaitu pada pemasaran 57,75 bungkus keripik singkong atau saat penjualan mencapai Rp 404.232,27 dengan HPP sebesar Rp 4.063,97. Analisis ini akan sangat berguna terutama jika pemilik usaha serius untuk mengembangkan produk menuju pasar retail modern ataupun dijual sendiri secara daring.

\section{Tahapan Implementasi}

Tahapan implementasi adalah tahap dimana pemilik usaha melaksanakan rancangan terpilih. Pemilik usaha akan mencoba memproduksi awal dengan menghasilkan 100 bungkus per bulan. Jumlah produksi ini diatas BEP produksi dan berharap mendapatkan dampak secara finansial terhadap usaha keripik singkong. Pemilik usaha juga mulai menjalin komunikasi dengan retail modern di wilayah Kabupaten Tanah Laut dan berharap produk dengan kemasan dan label baru ini bisa diterima.

\section{KESIMPULAN DAN SARAN}

\section{Kesimpulan}

Prioritas dalam pengembangan produk keripik singkong berbasis customer oriented dengan menggunakan metode value engineering berdasarkan survei yaitu dari segi kemasan dan desain label, bentuk kemasan standing pouch dengan rekomendasi kemasan standing pouch plastik, kertas, dan semi aluminium foil. Rekomendasi terpilih dari alternatif pengembangan produk keripik singkong berbasis customer oriented berdasarkan value engineering adalah bauran produk kemasan standing pouch plastik menggunakan label atas bawah dengan nilai prioritas 0.160 serta HPP sebesar Rp 4.063,97, BEP produksi sebesar Rp 404.232,80, BEP unit sebanyak 57,75 bungkus, NPV sebesar Rp 8.533.018,84, dan 
IRR $41,91 \%$. Secara umum proyek pengembangan layak untuk dijalankan.

\section{Saran}

Implementasi dari tahapan value engineering diharapkan tidak berhenti sampai disini. Pengembangan berkelanjutan (continuous improvement) dari aspek marketing mix terutama pada atribut produk secara periodik perlu terus di evaluasi. Pengembangan variasi rasa ataupun labeling halal perlu menjadi prioritas selanjutnya bagi UMKM ini.

\section{DAFTAR PUSTAKA}

Akbar RRE. 2011. Aplikasi Metode Analytic Hierarchy Process (AHP) untuk penentuan kriteria dominan penyebab beban kerja pada operator call center PT.X Cabang Bandung. Seminar Nasional Aplikasi Teknologi Informasi 2011. Yogyakarta, 17-18 Juni 2011.

Amanah D. 2010. Pengaruh harga dan kualitas produk terhadap kepuasan konsumen pada manjestyk bakery \& cake shop cabang $\mathrm{M}$. Yamin Medan. Jurnal Keuangan dan Bisnis. 2(1): 71-87. doi 10.17605.

Badan Standarisasi Nasional. 2006. Petunjuk Pengujian Organoleptik dan atau Sensori. SNI 01-2346-2006. Jakarta: Badan Standarisasi Nasional.

Darmawan MI, Hairiyah N, dan Hajar S. 2018. Analisis nilai tambah dan kelayakan usaha manisan terung ud. berkat motekar di desa pemuda kabupaten Tanah Laut. Jurnal Teknologi Agro-Industri. 5(2): 110-119. doi 10.25077 .

Darmawan MI, Ilmannafian AG, dan Iqbal M. 2020. Pengembangan amplang UD. Kelompok melati melalui metode value engineering berbasis marketing mix. Jurnal Teknologi Pertanian Andalas. 24(1): 1-6. doi 10.34128.

Hanifawati T, Suryatini A, dan Mulyo JH. 2017. Pengaruh atribut kemasan makanan dan karakteristik konsumen terhadap pembelian. Jurnal Sosial Ekonomi dan Kebijakan Pertanian Agriekonomika. 6(1): 72-85. doi 10.21107.

Ishafila A. Fatimah F, dan Eko W. 2018. Pengaruh harga, desain serta kualitas produk terhadap kepuasan konsumen. Jurnal Sains Manajemen dan Bisnis Indonesia. 8(2): 211-222. doi 10.32528 .

Ishak A dan Luthfi Z. 2011. Pengaruh kepuasan dan kepercayaan konsumen terhadap loyalitas: studi tentang peran mediasi switching costs. Jurnal Siasat Bisnis. 15(1): 55-66.
Khotimah H dan Sutiono. 2014. Analisis kelayakan finansial usaha budidaya bambu. Jurnal Ilmu Kehutanan, 8(1): 14-24. doi 10.22146.

Lukman MD. 2014. Analisis pengaruh ekuitas merek terhadap keputusan pembelian dan kepuasan konsumen produk teh botol sosro kemasan kotak. Jurnal Administrasi Bisnis. 10(1): 64-81.

Lumanauw B, Sepang J, dan Karim D. 2014. Marketing mix pengaruhnya terhadap volume penjualan pada PT Manado Sejati Perkasa Group. Jurnal Riset Ekonomi, Manajemen, Bisnis dan Akuntansi. 2(1): 421-430. doi10.35794.

Piligrimiene Z, Dovaliene A, dan Virvilaite R. 2015. Consumer Engagement in value co-creation : what kind of value it creates for company?. Engineering Economics. 26(4): 452-460. doi 10.5755 .

Pujianto T, Kastaman R, dan Utami I. 2016. Penerapan rekayasa nilai dalam pemilihan rancangan kemasan dan rasa produk dodol berdasar pada ketertarikan konsumen. Proceeding Seminar Nasional 215-226.

Reven D dan Ferdinand A. 2017. Analisis pengaruh desain produk, kualitas produk, harga kompetitif, dan citra merek terhadap keputusan pembelian (studi pada pelanga nesty collection jakarta). Diponegoro Journal of Management. 6(3): 1-13.

Rimantho D, Rachel M, Cahyadi B, Kurniawan Y. 2016. Aplikasi analitical hierarchy process pada pemilihan metode analisis zat organik dalam air. Jurnal Ilmiah Teknik Industri. 15(1): 47-56.

Rosita M, Hidayat K, dan Maflahah I. 2018. Analisis nilai tambah olahan ikan peperek (leiognathus equulus) menjadi ikan peperek crispy menggunakan metode Value Engineering. Jurnal Ilmiah Perikanan dan Kelautan. 15(1): 15-25. doi 10.20473.

Sadikin JY, Suryandono A, dan Jumeri. 2015. Pengembangan tortila berkalsium sebagai alternatif pangan diet casein free-gluten free pada industri kecil dengan metode Value Engineering. Agritech. 35(2): 212-222. doi 10.22146 .

Santoso B, Harianto, dan Sumanto. 2019. Sistem pendukung keputusan pemilihan paket umroh menggunakan metode AHP pada PT Shabilla Eraldo Utama. JIMP - Jurnal Informatika Merdeka Pasuruan. 4(2): 18-25. doi 10.37438.

Sudrajat AA dan Andriani DR. 2015. Pengaruh Atribut produk terhadap keputusan konsumen 
dalam pembelian produk abon jamur tiram di perusahaan AILANIFOOD Kota Malang Jawa Timur. Habitat. $26: 71-79$.

Susila B, Sumarwan U, dan Kirbrandoko. 2014. Analisis kepuasan konsumen terhadap brand switching behavior minuman teh dalam kemasan. Jurnal Ilmu Keluarga \& Konsumen. 7(3): 193-201. doi 10.24156.

Wahyudi R, Supartono W, dan Khuriyati N. 2013. Analisis mutu produk dan kemasan lempuk
Durian (Durio zibethinus sp.). Jurnal Industria. 2(1): 1-8.

Widodo P. 2010. Hubungan antara atribut produk terhadap keputusan pembelian minuman teh dalam kemasan. Jurnal Agribisnis dan Pengembangan Wilayah. 2(1). 